\section{Overview of withdrawal} syndrome mechanisms in different substance abuse \section{addictions: Neuronal circuits} and transmitters

\author{
Hamidreza Famitafreshi' and Morteza Karimian ${ }^{2 *}$ \\ ${ }^{1}$ Physiology Department, Tehran University of Medical Sciences-International Campus, Tehran, Iran \\ ${ }^{2}$ Physiology Department, Tehran University of Medical Sciences, Tehran, Iran
}

Received: 31 October, 2020

Accepted: 10 November, 2020

Published: 17 November, 2020

*Corresponding author: Morteza Karimian, Physiology Department, Tehran University of Medical Sciences, Tehran, Iran, Tel/Fax: 982166419484;

Email:karimian@tums.ac.ir

Keywords: Rewarding center; Endogenous cannabinoid system; Corticotropin-releasing factor; Orexin system and Locus coeruleus

https://www.peertechz.com

Check for updates

\begin{abstract}
Substance abuse is one of the major concerns of human societies. Many problems exist for controlling drug abuse that profoundly influences treatment. One of the most important and prevalent problems is Withdrawal Syndrome (WS). The WS describes a host of unpleasant symptoms that develop in the withdrawal period. WS should be suppressed in the withdrawal period because in the presence of WS dependence on drugs will continue. Using the drug to which one is addicted is the most effective way to suppress the withdrawal syndrome, which is why many users relapse after a period of abstinence. The purpose of this review article is to describe the basic brain mechanisms that are responsible for the emergence of WS that cannot be tolerated in the abstinence period. This may be helpful for a better understanding of the nature of WS in the withdrawal period for implementing the best approach with new insights for highlighting new horizons for future goal-directed studies. The important topics in this regard are non-related brain areas based on recent studies that have been proposed. They have included the rewarding center, endogenous cannabinoid system, corticotropin-releasing factor, locus coeruleus, and orexin system. According to the above facts, this syndrome arises with different mechanisms, and a multi-approach treatment toward this syndrome is required.
\end{abstract}

\section{Introduction}

Withdrawal Syndrome (WS) is undesired and unpleasant symptoms and signs that occur after cessation of abusing addictive substances [1,2]. Withdrawing from addictive substances may occur as a consequence of personal decision or in a clinical setting under the supervision of a clinician. There is a difference among individuals in the emergence of withdrawal signs and symptoms [3,4]. Needless to say, without WS, getting rid of substance abuse is much easier [5]. In the absence of WS, the development of dangerous addiction that manifests as compulsive drug seeking and taking behavior will be hindered [6]. From this prospect, treatment toward these signs and symptoms will reduce relapse to drug abuse [7]. WS is the emergence of unpleasant symptoms that has been well described in animal models and humans. The emergence of WS in the abstinence period will increase relapse to abuse drugs. So it would be reasonable to think that for controlling dependence, the undesired symptoms and signs should be suppressed.WS has been described as two-component: affective and somatic [8]. Both cause relapse to addiction. Affective symptoms include dysphoria, irritability, and anxiety, which might contribute to aversively motivated drug seeking [9] and somatic especially in animal models include diarrhea, facial fasciculations/teeth chattering, paw tremors, head shaking, swallowing, salivation, chromodacryorrhea, ptosis, abnormal posture, erection/ejaculation/genital grooming, and irritability $[10,11]$. This article aims to delineate the origin of such signs and symptoms and introduce new potential insights for therapy in such cases. However, based on recent studies, more than one region in the brain produces WS, independent of each other. So, they have been discussed separately. Also, it is noteworthy to say more studies especially in humans should be down to fully understand the context in which these symptoms appear. In Figure 1, a brief overview has been illustrated. 


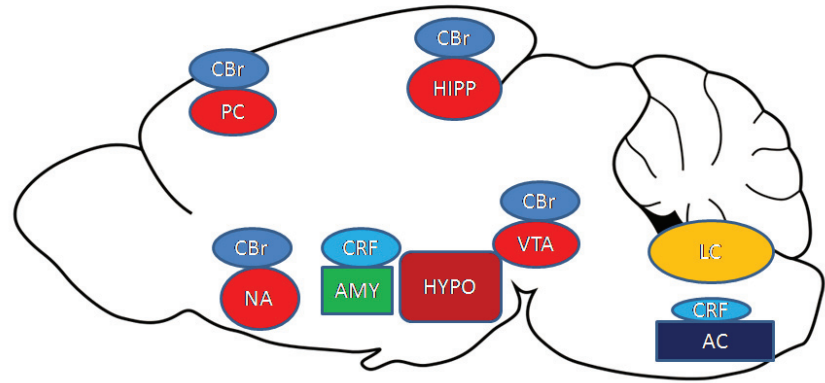

Figure 1: The above figure shows a different part of brain structures that are involved in withdrawal syndrome (WS) production.

Reward circuit components including Nucleus Accumbens (NA), Prefrontal Cortex (PC), Hippocampus (HIPP), and ventral tegmental area (VTA) are actively involved in WS. This circuit independently and also by the action of other systems produces WS. The Endogenous Cannabinoid System (ECS) is widely distributed in the brain and its receptors $\mathrm{CB} 1$ and $\mathrm{CB} 2$ are also found in different areas. $\mathrm{CB}$ receptors $(\mathrm{CBr})$ are found on the reward circuit component. Other mechanisms for ECS are not well understood. Corticotropin-Releasing hormone (CRF) is mainly secreted by the Hypothalamus (HYPO) and this hormone in producing WS has two mechanisms: direct action by stimulating the amygdala (AMY) and by an indirect pathway through activation of the autonomic center (AC). Hypothalamus (HYPO) also secreted orexin that was newly known for its direct action in the production of WS. Locus coeruleus (LC) secretes norepinephrine that causes the emergence of WS.

\section{Reward circuit}

Dopaminergic neurons in a reward circuit are a collection of neuronal structure that is responsible for incentive salience that is characterized by a craving for reward, motivation, learning, and mood $[12,13]$. The neuronal circuit connects different parts of brain structures such as cortical and midbrain components $[14,15]$. This important neuronal circuit is composed of different types of neuronal projections that are closely interconnected such as glutamatergic interneurons, GABAergic Medium Spiny Neurons (MSNs), dopaminergic projection neurons, and orexinergic projection neurons [16].

The reward system includes many different parts but little is known about the importance of these regions in producing WS. They have included the ventral tegmental area, striatum, substantia nigra, prefrontal cortex, cingulated cortex, insular cortex, hippocampus, hypothalamus, thalamus, subthalamic nucleus, globus pallidus, ventral pallidum, parabrachial nucleus, amygdala [17]. There are pieces of evidence that support reward center efficacy is necessary for the withdrawal period. It has been before well established that the crucial element in establishing addiction is overexpressed $\triangle F O S$ after dopamine release. Other behaviors that are established after dopamine release is self-administration and reward sensitization and cross-sensitization [18]. However, this may be the psychologic element of WS that may be related to drug abuse memory and not a physical component [19]. However, other studies explain other mechanisms for physical WS. WS can be explained in the best way with the concept of allostasis, the phenomena in which organisms tend to maintain the hemostasis despite stress $[20,21]$. Strong evidence supports the fact that the reward center's proper function is disturbed as the consequence of drug abuse [22-25]. Therefore, brain reward deficit may be a common affective component of withdrawal signs. Reward center insufficiency manifests itself in the withdrawal period through affective and emotional signs that include anxiety-like behavior, restlessness, and depression [26]. It is well established that for successful treatment of addiction some patients need psychotherapy. This is due to the presence of this affective component of withdrawal syndrome [27]. Recently the habenulo-interpeduncular region that is located in the thalamus is important to produce WS [28]. Habenulointerpeduncular region has a widespread connection to the reward center and helps the better function of the reward center and it has been suggested for better treatment of addiction this region should be taken into consideration [29].

\section{Endogenous cannabinoid system}

Endocannabinoid System (ECS) is a biological system composed of Endocannabinoid, which are endogenous lipidbased retrograde neurotransmitters that bind to cannabinoid receptors. This system has two types of receptors: CB1 and CB2 [30]. This system in normal physiologic condition causes no disturbance in normal body function, but upon an increase or decrease in ECStone, pathologic condition develops [31]. That is the result of altered expression of $\mathrm{CB}$ receptors, endocannabinoid metabolizing enzymes, and synthetic pathways. The CB1 receptor is a G-protein coupled receptor that mediates the psychoactive properties of delta9-tetrahydrocannabinol (THC) [32]. CB2 is most abundantly found in the animal brain such as rats in areas other than the reward circuit. CB1 is mostly concentrated in pre-synaptic areas and contrast $\mathrm{CB} 2$ mainly is located in post-synaptic areas [33]. However, the modulatory role of ECS on the reward center is thought to be related to the presence of cannabinoid receptors on VTA $[34,35]$. This action is not a direct action but rather is an indirect effect on retrograde synaptic transmission [36]. Previous studies have shown that the establishment of addiction can occur through ECS. However, if the establishment of addiction occurs as the result of the development of WS is not the case because WS occurs usually after the establishing of addiction. Many studies support the theory that ECS has a role in the establishing of addiction. Previous studies suggest that ECS has a role in the emergence of withdrawal syndrome [37]. This possibility rises when WS occurred after the chronic administration of cannabinoid antagonists. These observations raised the possibility that the cannabinoid antagonist produced rewarding effects, presumably by blocking either a dysphoric action or an inhibition of reward circuits produced by endogenous cannabinoids [38,39]. Experiments with other addictive drugs had the same result and confirm that ECS can be used as an effective target for the treatment of WS [4043]. ECS also mediates the rewarding effects of an addictive substance such as nicotine [44]. This suggests the pivotal role of ECS in the emergence of WS in the abstinence period. These findings suggest a new therapeutic strategy for the treatment of addiction [45].

Citation: Famitafreshi H, Karimian M (2020) Overview of withdrawal syndrome mechanisms in different substance abuse addictions: Neuronal circuits and transmitters. J Addict Med Ther Sci 6(1): 070-076. DOI: https://dx.doi.org/10.17352/2455-3484.000043. 


\section{Corticotropin releasing factor (CRF)}

Corticotropin-Releasing Factor (CRF), a 41 amino acidcontaining peptide, is secreted by the hypothalamus [46]. Besides the hypothalamus, this hormone has been discovered in cerebral cortical interneurons, the limbic system, brainstem, and spinal cord [47]. CRF receptors are G protein-coupled receptors and are two types: type 1 and type 2. Besides the pituitary, CRF receptors are also present in other brain areas such as the amygdala, locus coeruleus, and hippocampus. CRF is thought to be responsible for a wide range of neuropsychiatry disorders such as anxiety, depression, and also in substance abuse withdrawal period. It is the main hormone that is secreted in response to stress not only endocrine but also the autonomic and behavioral responses to stress [46]. Based on their important role in stress regulation different studies have been done to evaluate the efficacy of therapy [48]. Based on these studies CRF agonist and antagonist can be used in clinical settings but more studies are needed $[49,50]$. CRF has divergent effects on addiction. However, the role of CRF in the withdrawal period has been well established. Relapse can occur as the result of brain centers or through indirect pathways that are responsible for keeping the body in a steady state. The indirect pathways mainly occur through the insufficiency of the brain to control the body that is called allostasis. In this case, the body cannot adapt to new conditions and withdrawal signs occur by the activation of the autonomic system [51]. In this type of relapse is the appearance of anxiety, the emotional component of withdrawal syndrome occurs as the result of autonomic overstimulation $[52,53]$. In direct pathways, it has been proposed that CRF by direct stimulation of CRF receptors will cause the emergence of anxiety in the withdrawal period and this may increase the risk of relapse [54]. In different studies, CRF receptor antagonist diminished withdrawal syndrome [55, 56]. Also, another experiment revealed that CRF2 antagonist reduces the somatic expression of WS [57]. However, it should be noted CRF has two types of receptors including CRF1 and CRF2 and both types of blockage would diminish withdrawal signs $[58,59]$. The antagonist of CRF receptors also prevents a deficit in brain reward proper function [60]. Some studies have used systemic administration of agonist and antagonist of CRF receptors and localization of such useful effects has not well been described.

\section{Locus coeruleus (LC)}

Locus coeruleus is a nucleus in the pons of the brain stem that is the origin of physiological brain response to stress [61]. Norepinephrine is the brain mostly synthesized in this nucleus [62]. The locus coeruleus is responsible for mediating many of the sympathetic effects during stress [63]. In a stress state norepinephrine beside activation of the hypothalamicpituitary-adrenal axis directly increase sympathetic flow [64]. Moreover, LC in a stress state increases cognitive and emotion through the prefrontal cortex and nucleus accumbens, respectively [65]. Locus coeruleus has been hypothesized as one of the brain regions that most responsible for the occurrence of Withdrawal Syndrome (WS) [66,67]. The LC is rich with a cluster of noradrenergic neurons [68] and this nucleus has a high density of opiate receptors especially $\mu$ and $\mathrm{k}$ receptors [69-71]. The destruction of LC neurons reduces physical signs of opiate withdrawal [72]. Also, acute opiate administration in animal models reduces the firing rate of LC neurons [73]. However, after chronic administration reverse occurs and LC neurons will be hyperactive and will result in WS [74]. More studies revealed that LC is the main site of withdrawal syndrome and another afferent may potentiate this region as the origin of this syndrome. These afferents include the nucleus Paragigantocellularis (PGi) in the rostral ventrolateral medulla and the medial perifascicular area of the nucleus propositus hypoglossal ( $\mathrm{PrH})$ in the dorsomedial rostral medulla [75,76]. Not only opiate receptors but also NMDA receptors and AMPA receptors [77-82] have been known for this syndrome. In another study excitatory amino acid input has been proposed as the main mechanism for the occurrence of WS [83]. Enhanced serotonergic neurotransmission diminishes an augmented excitatory amino acid input to LC neurons that is responsible for most of their hyperactivity during opiate withdrawal [84]. More studies showed an injection of muscimol, a $\mathrm{GABA}_{\mathrm{A}}$ receptor agonist [85-87], and baclofen, a $\mathrm{GABA}_{\mathrm{B}}$ receptor agonist $[88,89]$, reduced naloxone-induced WS in morphine-dependent mice. Also, dopamine receptors especially D1 in LC interfere with the occurrence of WS [90]. Recent studies revealed more mechanisms for this purpose. Recently it has been proposed that orexin plays an important role in drug addiction $[88,91]$. Orexin neurons are located in the lateral hypothalamus, perifornical area, and dorsomedial hypothalamus and have extensive projections throughout the brain especially LC $[92,93]$. The blockage of orexin receptors in LC attenuates signs of naloxone-precipitated morphine withdrawal [94]. Galanin also inhibits the firing of LC neurons [95]. Modulation of galanin receptors in LC reduces WS signs [96].

\section{Orexin system}

Orexin, also known as hypocretin is a neuropeptide that is secreted by a cluster of neurons in the lateral hypothalamus and perifornical [97]. Orexinergic neurons receive different kinds of signals and projects richly to different parts of the brain such as the reward circuit. However, considering the number of neurons there are only 10,000 to 20,000 neurons in related brain areas. There are two types of orexin peptides (A and B) and two G-protein coupled receptors (orexin 1 and orexin 2) $[98,99]$. Connectivity and functionality of the orexin neurons in the two related brain areas known as lateral hypothalamus and perifornical are different. Orexinergic neurons in the lateral hypothalamus are closely associated with rewardassociated functions such as Conditioned Place Preference (CPP) and richly innervate the related brain areas such as the Ventral Tegmental Area (VTA) and prefrontal cortex [100] but neurons in perifornical areas are involved in autonomic function [101]. This system is inhibited and stimulated by different neurotransmitters. GABA (Gamma-Amino Butyric Acid), serotonin, and noradrenalin suppress the system and by contrast dopamine, cholecystokinin, neurotensin, oxytocin, and vasopressin activate this system. Glutamate can tonically affect orexinergic neurons [102]. This relatively newly 
discovered system (1998, for the first time) has been known as an important role in addiction. Recent shreds of evidence that showed this system can affect the addiction process come from studies that showed administration of orexin blockers hinder methamphetamine, nicotine, cocaine, alcohol, and opioids addiction [103-107]. Other studies showed orexin not just effective for the establishment of addiction but also can influence the reinstatement of pre-existing addiction [108]. The study result about nicotine is not consistent. For example, orexin-1 has reduced nicotine self-administration but other types cannot establish the same result [108]. It is known that naturally reinforces such as sugar and also addictive drugs both positively affect the reward circuit and this sense of orexin has a similar effect and is affected by both natural and addictive substances [109]. Based on the above study results, different sets of clinical trials were conducted to evaluate the orexintargeted therapy for dependence. Suvorexant is a synthetic orexin-like agent that has been recently been used as a novel treatment for cocaine-dependence and the preliminary result showed successful results [110]. In nicotine dependence, the studies are in the first steps and more studies should be done to get precise knowledge about the nature of orexin in nicotine dependence [111].

\section{Conclusion}

In this review article different mechanisms that cause the emergence of withdrawal syndrome were discussed. WS will not restrict one area in the brain but are related to different areas. Withdrawal syndrome is a great problem for stopping addiction because they are undesired and unwanted signs and symptoms and they are unrelated issues in the withdrawal period. In the absence of them, individuals will progress to quitting addition without difficulty. So, a better understanding of the nature of mechanisms behind them may help to establish effective management of this syndrome.

\section{References}

1. Witkiewitz K, Marlatt GA (2004) Relapse prevention for alcohol and drug problems: that was Zen, this is Tao. Am Psychol 59: 224-235. Link: https://bit.ly/36pMb68

2. Leshner $\mathrm{Al}$ (1997) Addiction is a brain disease, and it matters. Science 278 45-47. Link: https://bit.ly/2Uelwnj

3. Hendricks PS, Ditre JW, Drobes DJ, Brandon TH (2006) The early time course of smoking withdrawal effects. Psychopharmacology 187: 385-396. Link: https://bit.ly/38rS9WN

4. Fava GA, Gatti A, Belaise C, Guidi J, Offidani E (2015) Withdrawal symptoms after selective serotonin reuptake inhibitor discontinuation: a systematic review. Psychother Psychosom 84: 72-81. Link: https://bit.ly/3ki5CCK

5. Campos J, Roca L, Gude F, Gonzalez-Quintela A (2011) Long-term mortality of patients admitted to the hospital with an alcohol withdrawal syndrome Alcohol Clin Exp Res 35: 1180-1186. Link: https://bit.ly/36k2od7

6. Koob GF, Le Moal M (1997) Drug abuse: hedonic homeostatic dysregulation. Science 278: 52-58. Link: https://bit.ly/32vXjNQ

7. Leshner $\mathrm{Al}$ (2005) The essence of drug addiction. Link: https://bit.ly/2JWWOBf

8. Stoker AK, Semenova S, Markou A (2008) Affective and somatic aspects of spontaneous and precipitated nicotine withdrawal in C57BL/6J and BALB/ cByJ mice. Neuropharmacology 54: 1223-1232. Link: https://bit.ly/2lkYRTW
9. Nakagawa T, Yamamoto R, Fujio M, Suzuki Y, Minami M, et al. (2005) Involvement of the bed nucleus of the stria terminalis activated by the central nucleus of the amygdala in the negative affective component of morphine withdrawal in rats. Neuroscience 134: 9-19. Link: https://bit.ly/2Ue1klj

10. Wills KL, Parker LA (2016) Effect of pharmacological modulation of the endocannabinoid system on opiate withdrawal: a review of the preclinical animal literature. Frontiers in Pharmacology 7: 187. Link: https://bit.ly/2If3SNY

11. Mattioli L, Perfumi M (2011) Evaluation of Rhodiola rosea L. extract on affective and physical signs of nicotine withdrawal in mice. J Psychopharmacol 25 402-410. Link: https://bit.ly/2GQZtA4

12. Berridge KC (2007) The debate over dopamine's role in reward: the case for incentive salience. Psychopharmacology 191: 391-431. Link: https://bit.ly/3n6LnKj

13. Kalivas PW, Volkow ND (2005) The neural basis of addiction: a pathology of motivation and choice. Am J Psychiatry 162: 1403-1413. Link: https://bit.ly/2GLbkzs

14. Sesack SR, Grace AA (2010) Cortico-basal ganglia reward network: microcircuitry. Neuropsychopharmacology 35: 27-47. Link: https://bit.ly/3pfvHq4

15. Peters SK, Dunlop K, Downar J (2016) Cortico-striatal-thalamic loop circuits of the salience network: a central pathway in psychiatric disease and treatment Front Syst Neurosci 10: 104. Link: https://bit.ly/32swmuw

16. Haber SN, Knutson B (2010) The reward circuit: linking primate anatomy and human imaging. Neuropsychopharmacology 35: 4. Link: https://bit.ly/36mTuLP

17. Richard JM, Castro DC, DiFeliceantonio AG, Robinson MJ, Berridge KC (2013) Mapping brain circuits of reward and motivation: in the footsteps of Ann Kelley. Neurosci Biobehav Rev 37: 1919-1931. Link: https://bit.ly/2lkcLWa

18. Nestler EJ (2001) Molecular neurobiology of addiction. Am J Addict 10: 201 217. Link: https://bit.ly/3pgAc3C

19. Nestler EJ (2013) Cellular basis of memory for addiction. Dialogues Clin Neurosci 15: 431. Link: https://bit.ly/3eJkMjq

20. Koob GF, Le Moal M (2001) Drug addiction, dysregulation of reward, and allostasis. Neuropsychopharmacology 24: 97-129. Link: https://bit.ly/3pgyLC4

21. Schulteis G, Koob GF (1996) Reinforcement processes in opiate addiction: a homeostatic model. Neurochem Res 21: 1437-1454. Link: https://bit.ly/2lor9fO

22. Schulteis G, Markou A, Cole M, Koob GF (1995) Decreased brain reward produced by ethanol withdrawal. Proc Natl Acad Sci U S A 92: 5880-5884. Link: https://bit.ly/2JU9IVm

23. Kenny PJ, Chen SA, Kitamura O, Markou A, Koob GF (2006) Conditioned withdrawal drives heroin consumption and decreases reward sensitivity. J Neurosci 26: 5894-5900. Link: https://bit.ly/38uDiLw

24. Zhou FC, Anthony B, Dunn KW, Lindquist WB, Xu ZC, et al. (2007) Chronic alcohol drinking alters neuronal dendritic spines in the brain reward center nucleus accumbens. Brain Res 1134. Link: https://bit.ly/3n67q3N

25. Spielewoy C, Markou A (2003) Withdrawal from chronic phencyclidine treatment induces long-lasting depression in brain reward function. Neuropsychopharmacology 28: 1106. Link: https://bit.ly/2lc1Caf

26. Schulteis G, Liu J (2006) Brain reward deficits accompany withdrawa (hangover) from acute ethanol in rats. Alcohol 39: 21-28. Link: https://bit.ly/3n8MiK7

27. Quintanilla ME, Tampier L, Karahanian E, Rivera-Meza M, Herrera-Marschitz M, et al. (2012) Reward and relapse: complete gene-induced dissociation in an animal model of alcohol dependence. Alcohol Clin Exp Res 36: 517-522. Link: https://bit.ly/3pbKtOR

Citation: Famitafreshi H, Karimian M (2020) Overview of withdrawal syndrome mechanisms in different substance abuse addictions: Neuronal circuits and transmitters. J Addict Med Ther Sci 6(1): 070-076. DOI: https://dx.doi.org/10.17352/2455-3484.000043. 
28. Salas R, Sturm R, Boulter J, De Biasi M (2009) Nicotinic receptors in the habenulo-interpeduncular system are necessary for nicotine withdrawal in mice. J Neurosci 29: 3014-3018. Link: https://bit.ly/32LNY4L

29. Dani JA, De Biasi M (2013) Mesolimbic dopamine and habenulointerpeduncular pathways in nicotine withdrawal. Cold Spring Harb Perspect Med 3: a012138. Link: https://bit.ly/36mWfwU

30. Mackie K (2008) Cannabinoid receptors: where they are and what they do. J Neuroendocrinol 20. Link: https://bit.ly/3elnoOx

31. Pacher P, Bátkai S, Kunos G (2006) The endocannabinoid system as an emerging target of pharmacotherapy. Pharmacol Rev 58: 389-462. Link: https://bit.ly/3kdYk2T

32. Gamaleddin IH, Trigo JM, Gueye AB, Zvonok A, Makriyannis A, et al. (2015) Role of the endogenous cannabinoid system in nicotine addiction: nove insights. Front Psychiatry 6. Link: https://bit.ly/38Ajyps

33. Herkenham M, Lynn AB, Little MD, Johnson MR, Melvin LS, et al. (1990) Cannabinoid receptor localization in brain. Proc Natl Acad Sci U S A 87: 1932 1936. Link: https://bit.ly/3li6zfl

34. Fernández-Ruiz J, Hernández M, Ramos JA (2010) Cannabinoid-dopamine interaction in the pathophysiology and treatment of CNS disorders. CNS Neurosci Ther 16: e72-e91. Link: https://bit.ly/3liZATP

35. Melis M, Muntoni AL, Pistis M (2012) Endocannabinoids and the processing of value-related signals. Front Pharmacol 3. Link: https://bit.ly/3n9S2mZ

36. Melis M, Pistis M, Perra S, Muntoni AL, Pillolla G, et al. (2004) Endocannabinoids mediate presynaptic inhibition of glutamatergic transmission in rat ventral tegmental area dopamine neurons through activation of CB1 receptors. J Neurosci 24: 53-62. Link: https://bit.ly/2UcAEBK

37. Pacher P, Kunos G (2013) Modulating the endocannabinoid system in human health and disease-successes and failures. The FEBS J 280: 1918-1943. Link: https://bit.ly/3pem8HJ

38. Sañudo-Peña MC, Tsou K, Delay ER, Hohman AG, Force M, et al. (1997) Endogenous cannabinoids as an aversive or counter-rewarding system in the rat. Neurosci Lett 223: 125-128. Link: https://bit.ly/32x88PD

39. Cheer J, Kendall D, Marsden C (2000) Cannabinoid receptors and reward in the rat: a conditioned place preference study. Psychopharmacology 151: 25-30. Link: https://bit.ly/2UalwDN

40. Navarro M, Chowen J, Carrera MRA, del Arco I, Villanúa MA, et al. (1998) CB1 cannabinoid receptor antagonist-induced opiate withdrawal in morphinedependent rats. Neuroreport 9: 3397-3402. Link: https://bit.ly/32wnVy5

41. Navarro M, Carrera M, Fratta W, Valverde O, Cossu G, Fattore L, et al. (2001) Functional interaction between opioid and cannabinoid receptors in drug self administration. J Neurosci 21: 5344-5350. Link: https://bit.ly/2lkcNNC

42. Castañé A, Valjent E, Ledent C, Parmentier M, Maldonado R, et al. (2002) Lack of CB1 cannabinoid receptors modifies nicotine behavioural responses, but not nicotine abstinence. Neuropharmacology 43: 857-867. Link: https://bit.ly/2ljEp5F

43. Mitrirattanakul S, López-Valdés HE, Liang J, Matsuka Y, Mackie K, et al. (2007) Bidirectional alterations of hippocampal cannabinoid 1 receptors and thei endogenous ligands in a rat model of alcohol withdrawal and dependence. Alcohol Clin Exp Res 31: 855-867. Link: https://bit.ly/3eVirlL

44. Merritt LL, Martin BR, Walters C, Lichtman AH, Damaj MI (2008) The endogenous cannabinoid system modulates nicotine reward and dependence. J Pharmacol Exp Ther 326: 483-492. Link: https://bit.ly/3nmk52P

45. Piomelli D (2004) The endogenous cannabinoid system and the treatment of marijuana dependence. Neuropharmacology 47. Link: https://bit.ly/3khoSAy

46. Arborelius L, Owens M, Plotsky P, Nemeroff C (1999) The role of corticotropin- releasing factor in depression and anxiety disorders. J Endocrino 160: 1-12. Link: https://bit.ly/38prA4J

47. Taylor AL, Fishman LM (1988) Corticotropin-releasing hormone. New England Journal of Medicine 319: 213-222. Link: https://bit.ly/3lmOzkE

48. Gehlert DR, Cippitelli A, Thorsell A, Lê AD, Hipskind PA, et al. (2007) 3-(4-Chloro2-morpholin-4-yl-thiazol-5-yl)-8-(1-ethylpropyl)-2, 6-dimethyl-imidazo [1, 2-b] pyridazine: a novel brain-penetrant, orally available corticotropin-releasing factor receptor 1 antagonist with efficacy in animal models of alcoholism. J Neurosci 27: 2718-2726. Link: https://bit.ly/3lhpRSB

49. Ising M, Zimmermann US, Künzel HE, Uhr M, Foster AC, et al. (2007) Highaffinity CRF 1 receptor antagonist NBI-34041: preclinical and clinical data suggest safety and efficacy in attenuating elevated stress response. Neuropsychopharmacology 32: 1941-1949. Link: https://bit.ly/32uSNis

50. Spierling SR, Zorrilla EP (2017) Don't stress about CRF: assessing the translational failures of CRF 1 antagonists. Psychopharmacology 234: 14671481. Link: https://bit.ly/3lgFj13

51. George O, Le Moal M, Koob GF (2012) Allostasis and addiction: role of the dopamine and corticotropin-releasing factor systems. Physiol Behav 106: 58 64. Link: https://bit.ly/3kdM0zL

52. Valdez GR, Roberts AJ, Chan K, Davis H, Brennan M, et al. (2002) Increased ethanol self-administration and anxiety-like behavior during acute ethanol withdrawal and protracted abstinence: regulation by corticotropin-releasing factor. Alcohol Clin Exp Res 26: 1494-1501. Link: https://bit.ly/3eLI2gx

53. Stinus L, Cador M, Zorrilla EP, Koob GF (2005) Buprenorphine and CRF 1 antagonist block the acquisition of opiate withdrawal-induced conditioned place aversion in rats. Neuropsychopharmacology 30: 90. Link: https://bit.ly/3ltgNda

54. Corominas M, Roncero C, Casas M (2010) Corticotropin releasing factor and neuroplasticity in cocaine addiction. Life Sci 86: 1-9. Link: https://bit.ly/2IpPi62

55. Baldwin HA, Rassnick S, Rivier J, Koob GF, Britton KT (1991) CRF antagonist reverses the "anxiogenic" response to ethanol withdrawal in the rat Psychopharmacology 103: 227-232. Link: https://bit.ly/38ri7cX

56. Skelton KH, Oren D, Gutman DA, Easterling K, Holtzman SG, et al. (2007) The CRF1 receptor antagonist, R121919, attenuates the severity of precipitated morphine withdrawal. Eur J Pharmacol 571: 17-24. Link: https://bit.ly/3ki5IdC

57. Papaleo F, Ghozland S, Ingallinesi M, Roberts AJ, Koob GF, et al. (2008) Disruption of the CRF 2 receptor pathway decreases the somatic expression of opiate withdrawal. Neuropsychopharmacology 33: $2878 . \quad$ Link: https://bit.ly/36Be9w7

58. Ingallinesi M, Rouibi K, Le Moine C, Papaleo F, Contarino A (2012) CRF 2 receptor-deficiency eliminates opiate withdrawal distress without impairing stress coping. Molecular Psychiatry 17: 1283

59. George O, Ghozland S, Azar MR, Cottone P, Zorrilla EP, et al. (2007) CRFCRF1 system activation mediates withdrawal-induced increases in nicotine self-administration in nicotine-dependent rats. Proc Natl Acad Sci U S A 104 17198-17203. Link: https://bit.ly/38v2u4y

60. Bruijnzeel AW, Zislis G, Wilson C, Gold MS (2007) Antagonism of CRF receptors prevents the deficit in brain reward function associated with precipitated nicotine withdrawal in rats. Neuropsychopharmacology 32: 955. Link: https://bit.ly/35dEtN4

61. Sved AF, Cano G, Passerin AM, Rabin BS (2002) The locus coeruleus, Barrington's nucleus, and neural circuits of stress. Physiol Behav 77: 737-742. Link: https://bit.ly/2Ir52FS

62. Van Bockstaele E, Bajic D, Proudfit H, Valentino R (2001) Topographic architecture of stress-related pathways targeting the noradrenergic locus coeruleus. Physiol Behav 73: 273-283. Link: https://bit.ly/38sKB65

Citation: Famitafreshi H, Karimian M (2020) Overview of withdrawal syndrome mechanisms in different substance abuse addictions: Neuronal circuits and transmitters. J Addict Med Ther Sci 6(1): 070-076. DOI: https://dx.doi.org/10.17352/2455-3484.000043. 
63. Valentino RJ, Van Bockstaele E (2008) Convergent regulation of locus coeruleus activity as an adaptive response to stress. Eur J Pharmaco 583 194-203. Link: https://bit.ly/2lkyfSE

64. Abbott S, Kanbar R, Bochorishvili G, Coates M, Stornetta R, et al. (2012) C1 neurons excite locus coeruleus and A5 noradrenergic neurons along with sympathetic outflow in rats. J Physiol 590: 2897-2915. Link: https://bit.ly/2Uc0d5N

65. Benarroch EE (2009) The locus ceruleus norepinephrine system: functional organization and potential clinical significance. Neurology 73: 1699-1704. Link: https://bit.ly/3ncsXr

66. Rasmussen K, Beitner-Johnson DB, Krystal JH, Aghajanian GK, Nestle EJ (1990) Opiate withdrawal and the rat locus coeruleus: behavioral, electrophysiological, and biochemical correlates. J Neurosci 10: 2308-2317. Link: https://bit.ly/3elMaOx

67. Parlato R, Cruz H, Otto C, Murtra P, Parkitna JR, et al. (2010) Effects of the cell type-specific ablation of the cAMP-responsive transcription factor in noradrenergic neurons on locus coeruleus firing and withdrawal behavior after chronic exposure to morphine. J Neurochem 115: 563-573. Link: https://bit.ly/2IkHUZG

68. Sara SJ (2009) The locus coeruleus and noradrenergic modulation of cognition. Nat Rev Neurosci 10: 211-223. Link: https://bit.ly/3khvYEU

69. Selley DE, Nestler EJ, Breivogel CS, Childers SR (1997) Opioid receptor-coupled G-proteins in rat locus coeruleus membranes: decrease in activity after chronic morphine treatment. Brain Res 746: 10-18. Link: https://bit.ly/3eGz58s

70. Reyes B, Chavkin C, Van Bockstaele E (2010) Agonist-induced internalization of kappa-opioid receptors in noradrenergic neurons of the rat locus coeruleus. J Chem Neuroanat 40: 301-309. Link: https://bit.ly/3ppejPI

71. Moyse E, Marcel D, Leonard K, Beaudet A (1997) Electron microscopic distribution of mu opioid receptors on noradrenergic neurons of the locus coeruleus. Eur J Neurosci 9: 128-139. Link: https://bit.ly/38thAaz

72. Maldonado R, Koob GF (1993) Destruction of the locus coeruleus decrease physical signs of opiate withdrawal. Brain Res 605: 128-138. Link: https://bit.ly/3eLZcus

73. Valentino RJ, Wehby RG (1988) Morphine effects on locus ceruleus neurons are dependent on the state of arousal and availability of external stimuli: studies in anesthetized and unanesthetized rats. Pharmacol Exp Ther 244 1178-1186. Link: https://bit.ly/3lijKOn

74. Valentino RJ, Wehby RG (1989) Locus ceruleus discharge characteristics of morphine-dependent rats: effects of naltrexone. Brain Res 488: 126-134. Link: https://bit.ly/2lgY3ix

75. Aston-Jones G, Ennis M, Pieribone VA, Nickell WT, Shipley MT (1986) The brain nucleus locus coeruleus: restricted afferent control of a broad efferent network. Science 234: 734-737. Link: https://bit.ly/36pVh2K

76. Aston-Jones G, Shipley M, Chouvet G, Ennis M, Van Bockstaele E, et al. (1991) Afferent regulation of locus coeruleus neurons: anatomy, physiology and pharmacology. rog Brain Res 88: 47-75. Link: https://bit.ly/3eVFKff

77. Rasmussen K, Kendrick WT, Kogan JH, Aghajanian GK (1996) A selective AMPA antagonist, LY293558, suppresses morphine withdrawal-induced activation of locus coeruleus neurons and behavioral signs of morphine withdrawal. Neuropsychopharmacology 15: 497-505. Link: https://bit.ly/32uxxt7

78. Rasmussen K, Martin H, Berger JE, Seager MA (2005) The mGlu5 receptor antagonists MPEP and MTEP attenuate behavioral signs of morphine withdrawal and morphine-withdrawal-induced activation of locus coeruleus neurons in rats. Neuropharmacology 48: 173-180. Link: https://bit.ly/2Ub6sXF

79. Rasmussen K, Hsu MA, Vandergriff J (2004) The selective mGlu2/3 receptor antagonist LY341495 exacerbates behavioral signs of morphine withdrawal and morphine-withdrawal-induced activation of locus coeruleus neurons. Neuropharmacology 46: 620-628. Link: https://bit.ly/3pflgTq
80. Tokuyama S, Zhu H, Oh S, Ho K, Yamamoto T (2001) Further evidence for a role of NMDA receptors in the locus coeruleus in the expression of withdrawal syndrome from opioids. Neurochemistry International 39: 103-109. Link: https://bit.ly/38tjOSr

81. Rasmussen K, Fuller RW, Stockton ME, Perry KW, Swinford RM, et al. (1991) NMDA receptor antagonists suppress behaviors but not norepinephrine turnover or locus coeruleus unit activity induced by opiate withdrawal. Eur J Pharmacol 197: 9-16. Link: https://bit.ly/32xCZLX

82. Ozawa T, Nakagawa T, Sekiya Y, Minami M, Satoh M (2004) Effect of gene transfer of GLT-1, a glutamate transporter, into the locus coeruleus by recombinant adenoviruses on morphine physical dependence in rats. Eur $J$ Neurosci 19: 221-226. Link: https://bit.ly/3pdiCNO

83. Akaoka H, Aston-Jones G (1991) Opiate withdrawal-induced hyperactivity of locus coeruleus neurons is substantially mediated by augmented excitatory amino acid input. J Neurosci 11: 3830-3839. Link: https://bit.ly/3lhFLwg

84. Akaoka H, Aston-Jones G (1993) Indirect serotonergic agonists attenuate neuronal opiate withdrawal. Neuroscience 54: 561-565. Link: https://bit.ly/2JQ8ytT

85. Zarrindast MR, Mousa-Ahmadi E (1999) Effects of GABAergic system on naloxone-induced jumping in morphine-dependent mice. Eur J Pharmacol 381 129-133. Link: https://bit.ly/2JM7DKY

86. Mirzaii-Dizgah I, Karimian SM, Hajimashhadi Z, Riahi E, Ghasemi T (2008) Attenuation of morphine withdrawal signs by muscimol in the locus coeruleus of rats. Behav Pharmacol 19: 171-175. Link: https://bit.ly/3ljtA1T

87. Heikkilä AT, Echenko O, Uusi-Oukari M, Sinkkonen ST, Korpi ER (2001) Morphine withdrawal increases expression of GABAA receptor subunit mRNA in locus coeruleus neurons. Neuroreport 12: 2981-2985. Link: https://bit.ly/38zkOcN

88. Bexis S, Ong J, White J (2001) Attenuation of morphine withdrawal signs by the GABAB receptor agonist baclofen. Life Sci 70: 395-401. Link: https://bit.ly/2InBU2j

89. Kemmling A, Rubio M, Balerio G (2002) Baclofen prevents morphine withdrawa irrespective of seasonal variation. Behav Pharmaco 13: 87-92. Link: https://bit.ly/3el92xH

90. Dizgah IM, Karimian SM, Zarrindast MR, Sohanaki H (2005) Attenuation of morphine withdrawal signs by a D1 receptor agonist in the locus coeruleus of rats. Neuroreport 16: 1683-1686. Link: https://bit.ly/3kcq5ZH

91. Sharf R, Sarhan M, DiLeone RJ (2008) Orexin mediates the expression of precipitated morphine withdrawal and concurrent activation of the nucleus accumbens shell. Biol Psychiatry 64: 175-183. Link: https://bit.ly/2lpMKoH

92. Gompf HS, Aston-Jones G (2008) Role of orexin input in the diurnal rhythm of locus coeruleus impulse activity. Brain Res 1224. Link: https://bit.ly/38vbDdo

93. Peyron C, Tighe DK, Van Den Pol AN, De Lecea L, Heller HC, et al. (1998) Neurons containing hypocretin (orexin) project to multiple neuronal systems. J Neurosci 18: 9996-10015. Link: https://bit.ly/35gbPv1

94. Azizi H, Mirnajafi-Zadeh J, Rohampour K, Semnanian S (2010) Antagonism of orexin type 1 receptors in the locus coeruleus attenuates signs of naloxoneprecipitated morphine withdrawal in rats. Neurosci Lett 482: 255-259. Link: https://bit.ly/3n8EnMN

95. Sevcik J, Finta EP, Illes P (1993) Galanin receptors inhibit the spontaneous firing of locus coeruleus neurones and interact with $\mu$-opioid receptors. European Journal of Pharmacology 230: 223-230. Link: https://bit.ly/32vf6ot

96. Zachariou V, Brunzell DH, Hawes J, Stedman DR, Bartfai T, et al. (2003) The neuropeptide galanin modulates behavioral and neurochemical signs of opiate withdrawal. Proceedings of the National Academy of Sciences 100: 9028-9033. Link: https://bit.ly/35dQPoA

97. Kukkonen JP, Holmqvist T, Ammoun S, Åkerman KE (2002) Functions of

Citation: Famitafreshi H, Karimian M (2020) Overview of withdrawal syndrome mechanisms in different substance abuse addictions: Neuronal circuits and transmitters. J Addict Med Ther Sci 6(1): 070-076. DOI: https://dx.doi.org/10.17352/2455-3484.000043. 
the orexinergic/hypocretinergic system. Am J Physiol Cell Physiol 283 C1567-C1591. Link: https://bit.ly/35cxCnc

98. Boss C, Roch C (2015) Recent trends in orexin research-2010 to 2015. Bioorganic \& medicinal chemistry letters 25: 2875-2887. Link: https://bit.ly/2lk9hD5

99. Marcus JN, Elmquist JK (2006) Orexin projections and localization of orexin receptors. The Orexin/Hypocretin System: Springer; 21-43. Link: https://bit.ly/3pdUE55

100. Aston-Jones G, Smith RJ, Sartor GC, Moorman DE, Massi L, et al. (2010) Lateral hypothalamic orexin/hypocretin neurons: a role in reward-seeking and addiction. Brain Res 1314: 74-90. Link: https://bit.ly/3khUo1k

101. Grimaldi D, Silvani A, Benarroch EE, Cortelli P (2014) Orexin/hypocretin system and autonomic control: new insights and clinical correlations. Neurology 82: 271-278. Link: https://bit.ly/36jnDff

102. Chieffi S, Carotenuto M, Monda V, Valenzano A, Villano I, Precenzano F, et al. (2017) Orexin system: the key for a healthy life. Frontiers in Physiology 8. Link: https://bit.ly/3kpmc41

103. Harris GC, Wimmer M, Aston-Jones G (2005) A role for lateral hypothalamic orexin neurons in reward seeking. Nature 437: 556-559. Link: https://bit.ly/2GPZrsa

104. Smith RJ, See RE, Aston-Jones G (2009) Orexin/hypocretin signaling at the orexin 1 receptor regulates cue-elicited cocaine-seeking. Eur J Neurosci 30 : 493-503. Link: https://bit.ly/3kgFhoP
105. Lawrence AJ, Cowen MS, Yang HJ, Chen F, Oldfield B (2006) The orexin system regulates alcohol-seeking in rats. $\mathrm{Br} \mathrm{J}$ Pharmacol 148: 752. Link: https://bit.ly/36oazVM

106. Uslaner JM, Winrow CJ, Gotter AL, Roecker AJ, Coleman PJ, et al. (2014) Selective orexin 2 receptor antagonism blocks cue-induced reinstatement, but not nicotine self-administration or nicotine-induced reinstatement. Behav Brain Res 269. Link: https://bit.ly/3pmPsMv

107. Lee C, Bae HJ, Jang JH, Park GH (2020) Investigating the Roles of Orexinergic System in Methamphetamine-induced Addiction. The FASEB Journal 34. Link: https://bit.ly/2Uc4KVN

108. Khoo SYS, McNally GP, Clemens KJ (2017) The dual orexin receptor antagonist TCS1102 does not affect reinstatement of nicotine-seeking PloS One 12: e0173967. Link: https://bit.ly/3knKKuc

109. Saad L, Sartori M, Bodetto SP, Romieu P, Kalsbeek A, et al. (2019) Regulation of brain DNA methylation factors and of the orexinergic system by cocaine and food self-administration. Mol Neurobiol 56: 5315-5331. Link: https://bit.ly/36pm3bJ

110. Simmons SJ, Gentile TA (2020) Cocaine abuse and midbrain circuits: Functional anatomy of hypocretin/orexin transmission and therapeutic prospect. Brain Res 1731. Link: https://bit.ly/38sVHIh

111. Khoo SYS, McNally GP, Clemens KJ (2019) The orexin system and nicotine addiction: preclinical insights. Neuroscience of Nicotine: Elsevier 509-517.

\section{Discover a bigger Impact and Visibility of your article publication with} Peertechz Publications

\section{Highlights}

- Signatory publisher of ORCID

* Signatory Publisher of DORA (San Francisco Declaration on Research Assessment)

- Articles archived in worlds' renowned service providers such as Portico, CNKI, AGRIS TDNet, Base (Bielefeld University Library), CrossRef, Scilit, J-Gate etc.

* Journals indexed in ICMJE, SHERPA/ROMEO, Google Scholar etc.

* OAI-PMH (Open Archives Initiative Protocol for Metadata Harvesting)

* Dedicated Editorial Board for every journa

* Accurate and rapid peer-review process

* Increased citations of published articles through promotions

* Reduced timeline for article publication

Submit your articles and experience a new surge in publication services (https://www.peertechz.com/submission).

Peertechz journals wishes everlasting success in your every endeavours.

Copyright: @ 2020 Famitafreshi $\mathrm{H}$, et al. This is an open-access article distributed under the terms of the Creative Commons Attribution License, which permits unrestricted use, distribution, and reproduction in any medium, provided the original author and source are credited.

Citation: Famitafreshi H, Karimian M (2020) Overview of withdrawal syndrome mechanisms in different substance abuse addictions: Neuronal circuits and transmitters. J Addict Med Ther Sci 6(1): 070-076. DOI: https://dx.doi.org/10.17352/2455-3484.000043. 